\title{
Biochemical and Genetical Analysis of Rhizobium meliloti Mutants Defective in $\mathrm{C}_{4}$-dicarboxylate Transport
}

\author{
By TH. ENGELKE, M. N. JAGADISH† AND A. PÜHLER* \\ Lehrstuhl für Genetik, Fakultät für Biologie, Universität Bielefeld, 48 Bielefeld 1, FRG
}

(Received 9 April 1987; revised 3 July 1987)

\begin{abstract}
Inhibition studies with free-living cells of Rhizobium meliloti 2011 showed that succinate, fumarate and malate are transported via a common transport system. It is an active process that is inducible by succinate. The apparent $K_{\mathrm{m}}$ for succinate uptake in free-living cells is $5 \cdot 3 \mu \mathrm{M}$. Seven Tn5-induced mutants that did not grow on succinate, fumarate or malate lacked the $\mathrm{C}_{4}$ dicarboxylate transport system in the free-living state (Dctfl-). Five of these mutants (RMS11, RMS16, RMS17, RMS24, RMS118) induced nodules on alfalfa with about half the nitrogenfixation activity of the wild-type (Fix ${ }^{\text {red }}$ ). The remaining two mutants (RMS420 and RMS938) gave rise to small, white and ineffective nodules on alfalfa $\left(\mathrm{Fix}^{-}\right)$. These results correlated with the dicarboxylate transport rates of bacteroids isolated from appropriate nodules: bacteroids isolated from nodules induced by the Fix ${ }^{\text {red }}$ mutants transported succinate or malate at about 30 $50 \%$ of the wild-type rate (Dcts ${ }^{\text {red }}$ ), whereas bacteroids isolated from nodules induced by $\mathrm{Fix}^{-}$ mutants showed no uptake activity (Dcts ${ }^{-}$). From an $R$. meliloti 2011 bank three cosmids were identified which complemented different Dctfl- mutants. Complemented Dctfl- mutants could grow again on agar containing succinate or malate. In the case of $\mathrm{Fix}^{-}$mutants complementation resulted in effective nodules. The cosmids $\mathrm{pRmSC101}$ and $\mathrm{pRmSC} 102$ complemented the Fix ${ }^{-}$mutant RMS420. A third cosmid, pRmSC121, complemented the second Fix ${ }^{-}$mutant RMS938 and nearly all of the Fix ${ }^{\text {red }}$ mutants. For the Fix ${ }^{-}$mutant RMS420 the $\operatorname{Tn} 5$ insertion site was found to be located on a $15 \cdot 3$ EcoRI fragment which is also part of the complementing cosmid pRmSC102.
\end{abstract}

\section{INTRODUCTION}

In the nitrogen-fixation process of the Rhizobium-legume symbiosis, a large amount of energy is required for the enzyme nitrogenase to reduce atmospheric nitrogen to ammonia. It is therefore of interest to identify the carbon compounds supplied by the plant and taken up by bacteroids. It is unlikely that sugars are used as energy source for nitrogen fixation because mutants of R. leguminosarum (Glenn et al., 1984; McKay et al., 1985), R. meliloti (Duncan, 1981) and ' $R$. trifolii' ( $R$. leguminosarum biovar trifolii) (Ronson \& Primrose, 1979) defective in sugar metabolism are not affected in nitrogen fixation. Bacteroids of $R$. leguminosarum are also unable to transport glucose (Hudman \& Glenn, 1980; De Vries et al., 1982) or to oxidize it (Glenn \& Dilworth, 1981). In addition, Saroso et al. (1986) reported the peribacteroid membrane of a cowpea Rhizobium strain to be relatively impermeable to sugars. On the other hand, a functional tricarboxylic acid cycle and an intact transport system for dicarboxylic acids seem to be important for effective nitrogen fixation. Mutants of $R$. leguminosarum (Finan et al., 1981) and $R$. meliloti (Gardiol et al., 1982) with a defective succinate dehydrogenase, and a further $R$. meliloti mutant with a defective 2-oxoglutarate dehydrogenase (Duncan \& Fraenkel, 1979)

† Present address: CSIRO, Division of Protein Chemistry, 343 Royal Parade, Parkville 3052, Victoria, Australia.

Abbreviation: DNP, dinitrophenol.

0001-4130 (C) 1987 SGM 
induced ineffective nodules. Mutants of R. leguminosarum (Glenn et al., 1980; Finan et al., 1981, 1983; Arwas et al., 1985) and two Bradyrhizobium species (San Francisco \& Jacobson, 1985), unable to transport succinate, fumarate or malate in the bacteroid state, did not show nitrogenfixation activity. In contrast, a few mutants were found which had no transport activity in the free-living condition but still fixed nitrogen in the symbiotic state (Finan et al., 1983; Arwas et al., 1985). R. meliloti mutants (Bolton et al., 1986) and ' $R$. trifolii' mutants (Ronson et al., 1981) that were unable to transport succinate in the free-living state were also unable to induce an effective symbiosis with alfalfa.

In this paper we describe investigations of the dicarboxylate transport system of $R$. melilot $i$ in both the free-living and the symbiotic state, and report the isolation of Tn5-induced mutants to find out how nitrogen fixation in $R$. meliloti is dependent upon a functional $\mathrm{C}_{4}$-dicarboxylate transport system.

\section{METHODS}

Bacterial strains and plasmids. These are listed in Table 1.

Media and growth conditions. Escherichia coli cells were grown in LB medium ( $1 \%$, w/v, Bacto-tryptone, $0.5 \%$ yeast extract and $0.5 \% \mathrm{NaCl}$ ), in LBMM medium ( $\mathrm{LB}$ plus $4 \mathrm{~g} \mathrm{MgCl}_{2}$ and $1 \mathrm{~g}^{2}$ maltose $\mathrm{l}^{-1}$ ), in Penassay broth or in TY medium $\left(0.5 \%\right.$ Bacto-tryptone, $0.3 \%$ yeast extract and $\left.0.1 \% \mathrm{CaCl}_{2}\right)$, at $37{ }^{\circ} \mathrm{C}$ unless otherwise mentioned. $R$. meliloti cells were grown in TY medium or in minimal medium at $30^{\circ} \mathrm{C}$. Rhizobium minimal medium contained: $12 \mathrm{mM}-\mathrm{K}_{2} \mathrm{HPO}_{4}, 11 \mathrm{~mm}-\mathrm{KH}_{2} \mathrm{PO}_{4}, 2.5 \mathrm{~mm}-\mathrm{NaCl}, 6.3 \mathrm{~mm}-\mathrm{NH}_{4} \mathrm{NO}_{3}, 2.0 \mathrm{mM}-\mathrm{MgSO}_{4}, 70 \mu \mathrm{M}-\mathrm{CaCl}_{2}$, plus $1 \mathrm{mg}$ each of biotin, thiamin and calcium pantothenate $1^{-1}(\mathrm{pH}, 6 \cdot 5)$. Biotin, thiamin and calcium pantothenate were filter-sterilized separately. Carbon substrates, all filter-sterilized, were added at a final concentration of $10 \mathrm{~mm}$. Growth rates were estimated by measuring $\mathrm{OD}_{580}$ (Kontron Uvikon 820$)$. For growth on solid medium $1.5 \%(\mathrm{w} / \mathrm{v})$ agar was added. Antibiotics were used at the following concentrations: ampicillin (Ap) $50 \mu \mathrm{g} \mathrm{ml}^{-1}$, tetracycline (Tc) $5 \mu \mathrm{g} \mathrm{ml}^{-1}$, chloramphenicol (Cm) $50 \mu \mathrm{g} \mathrm{ml}^{-1}$, kanamycin $(\mathrm{Km}) 25 \mu \mathrm{g} \mathrm{ml}^{-1}$, neomycin $(\mathrm{Nm}) 100 \mu \mathrm{g} \mathrm{ml}^{-1}$ and streptomycin (Sm) $400 \mu \mathrm{g} \mathrm{ml}^{-1}$.

Plant assays. Alfalfa seeds were surface-sterilized with $32 \%(\mathrm{v} / \mathrm{v}) \mathrm{HCl}$ for $15 \mathrm{~min}$, then washed twice with $100 \mathrm{ml}$ $70 \%(\mathrm{v} / \mathrm{v})$ ethanol and three times with $100 \mathrm{ml}$ sterile $\mathrm{H}_{2} \mathrm{O}$. The seeds were incubated in the dark for $36 \mathrm{~h}$ in Petri dishes on nitrogen-free medium which contained: $1.2 \mathrm{~mm}-\mathrm{K}_{2} \mathrm{HPO}_{4}, 0.4 \mathrm{~mm}-\mathrm{KH}_{2} \mathrm{PO}_{4}, 5 \mathrm{~mm}-\mathrm{CaCl}_{2}, 3.35 \mathrm{mg}$ ferric citrate $1^{-1}, 2.5 \mathrm{~mm}-\mathrm{MgSO}_{4}, 2.5 \mathrm{~mm}-\mathrm{K}_{2} \mathrm{SO}_{4}, 10 \mu \mathrm{M}-\mathrm{MnSO}_{4}, 20 \mu \mathrm{M}-\mathrm{H}_{3} \mathrm{BO}_{3}, 5 \mu \mathrm{M}-\mathrm{ZnSO}_{4}, 0 \cdot 2 \mu \mathrm{M}-\mathrm{CuSO}_{4}$, $1.5 \mu \mathrm{M}-\mathrm{CaSO}_{4}, 1.0 \mu \mathrm{M}-\mathrm{NaMoO}_{4}$ and $10 \mathrm{~g}$ agar $1^{-1}(\mathrm{pH}, 6 \cdot 8)$. Three seedlings were transferred to each fresh Petri dish containing alfalfa growth medium which had been preinoculated with about $10^{8}$ bacteria. After $24 \mathrm{~d}$ incubation at $20^{\circ} \mathrm{C}$ and $70 \%$ humidity, plants were harvested and incubated with acetylene. After $1 \mathrm{~h}$, acetylene reduction capacity was measured by gas chromatography (Hewlett Packard 5710A).

Preparation of bacteroids. The procedure used is a modification of that described by Finan et al. (1983). Nodules were harvested from 21 -d-old plants. In the case of effective nodules 40 plants, and in the case of ineffective nodules 120 plants, were usually sufficient to obtain enough nodule material. The harvested nodules were placed in $10 \mathrm{ml}$ cold MMS buffer (40 mM-MOPS, $20 \mathrm{mM}-\mathrm{KOH}, 2 \mathrm{~mm}-\mathrm{MgSO}_{4}$ and $300 \mathrm{~mm}$-sucrose, pH 6.5, and homogenized in a mortar to release the bacteroids. The homogenate was filtered through eight layers of

\section{Table 1. Bacterial strains and plasmids}

Strain

E. coli $\mathrm{SM} 10$

E. coli $\mathrm{K} 802$

E. coli $\mathrm{S} 605$

E. coli $\mathrm{S} 17.1$

R. meliloti 2011 pSUP205

pSUP2021

pSUP5011 pNC206
Relevant characteristics

thi thr leu suIII recA $\mathrm{Km}^{\mathrm{r}}$, containing RP4-2(Tc: : Mu) integrated into the chromosome hsdR hsdM gal met supE thi thr leu suIII lac met:: $\mathrm{Tn} 5 \mathrm{Km}^{\mathrm{r}}$

pro Res $^{-} \mathrm{Mod}^{+} \operatorname{rec} A$, containing RP4 integrated into the chromosome

$\mathrm{Sm}^{\mathrm{r}}$

$\mathrm{Cm}^{\mathrm{r}} \mathrm{Tc}^{\mathrm{r}}$, a pBR325 derivative containing the $\lambda$ cos site and the RP4 Mob site

$\mathrm{Ap}^{\mathrm{r}} \mathrm{Cm}^{\mathrm{r}} \mathrm{Nm}^{\mathrm{r}}$, a pBR325 derivative

A pBR325 derivative containing Tn 5 and the RP4 Mob site $A^{5} \mathrm{Km}^{\mathrm{r}}$, a derivative of $\mathrm{RP} 4$

\section{Reference}

Simon et al. (1983)

Maniatis et al. (1982)

R. Simon, Bielefeld

Simon et al. (1983)

J. Denarie, France

Simon et al. (1983)

Simon et al. (1983)

Simon et al. (1983)

D. Haas, ETH Zürich 
cheesecloth and centrifuged at $400 \mathrm{~g}$ for $10 \mathrm{~min}$ to sediment plant cells and cell fragments. The supernatant was centrifuged at $2000 \mathrm{~g}$ for $10 \mathrm{~min}$. The resulting pellet contained the bacteroid fraction as judged by microscopic examination. This fraction was washed three times with transport buffer (see below). The whole procedure was carried out at $4{ }^{\circ} \mathrm{C}$

Uptake experiments. The method used is a modification of that described by Finan et al. (1981). An exponentialphase culture of free-living $R$. meliloti was centrifuged at $4000 \mathrm{~g}$. The cells were washed, like the bacteroids, three times with cold $\left(4{ }^{\circ} \mathrm{C}\right)$ transport buffer $\left(4 \mathrm{~mm}-\mathrm{MgSO}_{4}, 20 \mathrm{~mm}-\mathrm{NH}_{4} \mathrm{Cl}, 0 \cdot 1 \mathrm{mM}-\mathrm{KH}_{2} \mathrm{PO}_{4}, 1 \cdot 2 \mathrm{mM}-\mathrm{K}_{2} \mathrm{HPO}_{4}, 20 \mathrm{mM}^{-}\right.$ $\left.\mathrm{KOH}, 0.2 \mathrm{mM}-\mathrm{CaCO}_{3}, 40 \mathrm{~mm}-\mathrm{MOPS}, \mathrm{pH} \mathrm{6.5}\right)$ and resuspended in fresh transport buffer $\left(4^{\circ} \mathrm{C}\right)$. The sample was incubated at $30^{\circ} \mathrm{C}$ for $10 \mathrm{~min}$ before adding $\left[2,3^{14} \mathrm{C}\right]$ succinate (Amersham). In experiments in which 2,4dinitrophenol (DNP) was present, cells were preincubated for $10 \mathrm{~min}$ at $30^{\circ} \mathrm{C}$ with DNP before adding $\left[{ }^{14} \mathrm{C}\right]$ succinate. Usually, at time intervals of $20 \mathrm{~s}, 100 \mu \mathrm{l}$ culture samples were withdrawn, vacuum-filtered using nitrocellulose filters with a pore size of $0.45 \mu \mathrm{m}$ (Sartorius), and washed with $5 \mathrm{ml}$ cold transport buffer. The filters containing cells were dried at $100{ }^{\circ} \mathrm{C}$ for $30 \mathrm{~min}$ and resuspended in $5 \mathrm{ml}$ scintillation fluid containing $3.5 \mathrm{~g}$ PPO and $0.2 \mathrm{~g}$ POPOP per litre toluene. ${ }^{14} \mathrm{C}$ radioactivity was measured in a scintillation counter (Hewlett Packard TriCarb 300). Non-specific binding of $\left[{ }^{14} \mathrm{C}\right]$ succinate to the outer cell wall was estimated by incubating the reaction mixture with $2 \%(\mathrm{v} / \mathrm{v})$ toluene for $30 \mathrm{~min}$ at $30^{\circ} \mathrm{C}$ prior to the addition of $\left[{ }^{14} \mathrm{C}\right]$ succinate. Protein concentration was measured by the Lowry method with lysozyme (Serva) as a standard.

Recombinant DNA methods. Cosmid DNA from E. coli was prepared on a large scale by a caesium chloride centrifugation essentially as described by Clewell \& Helinski (1969) or on a small scale by the rapid isolation procedure described by Ish-Horowicz \& Burke (1981) with the following modification. The supernatant, before ethanol precipitation, was treated with $0.44 \%$ diethyl pyrocarbonate (Sigma) for $15 \mathrm{~min}$ at $65^{\circ} \mathrm{C}$ to inactivate the residual proteins. After incubation, the mixture was microfuged for $2 \mathrm{~min}$ and the supernatant was transferred to a fresh tube and ethanol precipitated. The $E$. coli transformation procedure, isolation of Rhizobium DNA, agarose gel electrophoresis and Southern hybridization have been described before (Jagadish \& Szalay, 1984). Restriction enzymes (EcoRI, HindIII) were used according to the manufacturer's specifications.

A cosmid gene bank of $R$. meliloti 2011 , constructed in $E$. coli K802 using the cosmid vector pSUP205, was available (Hynes et al., 1986).

Bacterial matings for transfer of plasmid/cosmid DNA. E. coli and Rhizobium cells were grown in liquid medium to late-exponential phase, mixed in a 1:1 ratio in Eppendorf tubes, microfuged and resuspended in 25-50 $\mu 1 \mathrm{TY}$ medium. Portions $(20-30 \mu \mathrm{l})$ of this suspension were spotted onto sterile filters (Sartorius) placed on TY agar. After incubation at $30^{\circ} \mathrm{C}$ for $15-24 \mathrm{~h}$, the filters were resuspended in $1 \mathrm{ml}$ sterile water if the recipient was $R$. meliloti, or $1 \mathrm{ml}$ fresh TY medium if the recipient was $E$. coli. Undiluted or serially diluted samples were plated onto appropriate selective plates (containing tetracycline and streptomycin) for the growth of transconjugants.

A cosmid gene bank stored as a $\lambda$ lysate was transfected into $E$. coli $\mathrm{S} 17.1$ in the following way: $0 \cdot 1 \mathrm{ml}$ lysate was added to $5 \mathrm{ml}$ of $E$. coli $\mathrm{S} 17.1$ strain grown in LBMM to exponential phase, mixed and incubated at $37^{\circ} \mathrm{C}$ with gentle shaking for $30 \mathrm{~min}$. E. coli $\mathrm{S} 17.1$ now containing the cosmid bank was mated en masse to the $R$. meliloti mutants as described above.

Isolation of $R$. meliloti dicarboxylate transport mutants by Tn5 mutagenesis. The Tn5 mutagenesis system developed by Simon (Simon et al., 1983; Simon, 1984) was used. E. coli SM10, containing RP4-2(Tc::Mu) integrated into the chromosome (to provide $\mathrm{Tra}^{+}$functions during mating) and a plasmid (pSUP2021) carrying Tn5 $\left(\mathrm{Nm}^{\mathrm{r}} \mathrm{Km}^{\mathrm{r}}\right)$, was mated with $R$. meliloti $2011\left(\mathrm{Sm}^{\mathrm{r}}\right)$. Transconjugants were selected on TY agar plates containing neomycin and streptomycin. The $\mathrm{Sm}^{r} \mathrm{Nm}^{r}$ transconjugants were subsequently screened in parallel on Rhizobium minimal medium containing glucose $(10 \mathrm{mM})$ or succinate $(10 \mathrm{~mm})$ to select for mutants that grew on glucose but not on succinate. This procedure excluded mutants defective in amino acid or nucleotide biosynthetic pathways.

Isolation of cosmid clones that complement $C_{4}$-dicarboxylate transport mutants. A cosmid gene bank of $R$. meliloti 2011 in pSUP205 (stored in E. coli K802 or as a $\lambda$ lysate) was used for the isolation of clones able to complement the $R$. meliloti dicarboxylate transport mutants. This was achieved by mobilizing the cosmids into $E$. coli using IncPgroup plasmid RP4 and transferring them into $R$. meliloti. Several pooled batches of the bank containing RP4 (cells were $\mathrm{Tc}^{r}$ due to the cosmid vector $\mathrm{pSUP} 205$ and $\mathrm{Ap}^{\mathrm{r}}$ due to RP4) were mated en masse with the $R$. meliloti dicarboxylate transport mutants. Cosmids, stored as a $\lambda$ lysate, were introduced by transfection into $E$. coli $\mathrm{S} 17.1$, which was then mated en masse with the different $R$. meliloti mutants again. As pSUP205 is unable to replicate autonomously in $R$. meliloti, it can only survive by integrating into the genome. Since the cosmids contain $R$. meliloti DNA the integration normally occurs via crossing-over in the homologous region. Each mating mixture was plated on TY agar plus streptomycin and tetracycline to determine the frequency of mobilization of cosmids into $R$. meliloti. By additional selection on minimal medium plus streptomycin and tetracycline and with succinate as sole carbon source, cosmid clones were isolated that complemented the mutants, enabling them to utilize succinate again. By mating an RP4-derivative (pNC206) into the mutants, spontaneously excised cosmids could be mobilized back into $E$. coli $\mathrm{S} 17.1$, where they could be further analysed. 


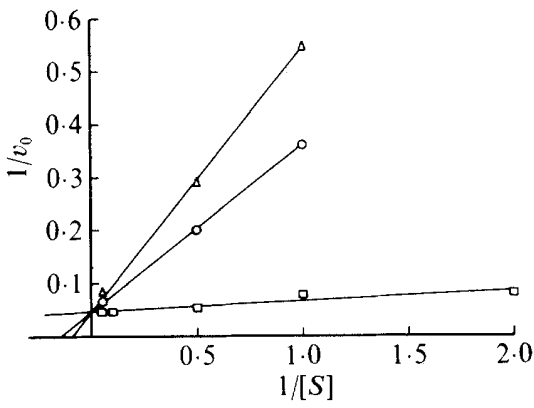

Fig. 1

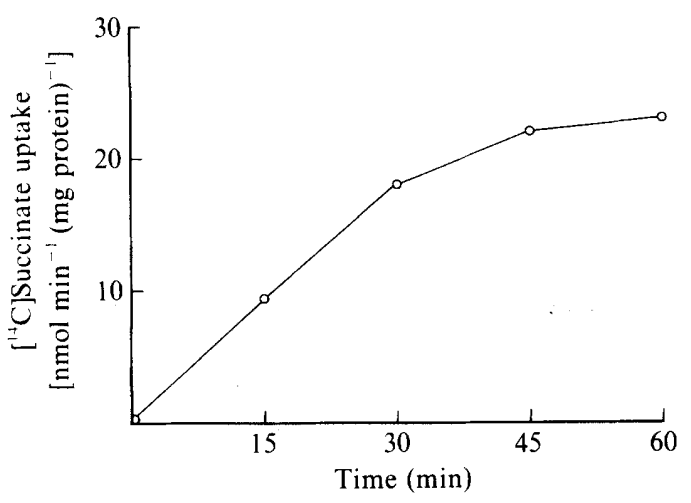

Fig. 2

Fig. 1. Competitive inhibition of succinate uptake by fumarate and malate in $R$. meliloti 2011. $\left[{ }^{14} \mathrm{C}\right]$ Succinate uptake rates were measured for five succinate concentrations without inhibitor $(\square)$, for three succinate concentrations plus $0.1 \mathrm{~mm}$-fumarate $(\triangle)$ and for three succinate concentrations plus

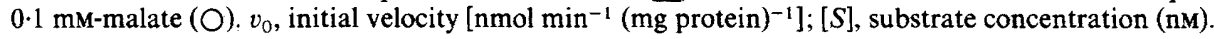

Fig. 2. Induction of the dicarboxylate transport system in $R$. meliloti 2011. Cells were centrifuged after growth in minimal medium plus glucose $(10 \mathrm{mM})$, washed and resuspended in minimal medium plus succinate $(10 \mathrm{mM})$. From this culture samples were withdrawn at intervals of $15 \mathrm{~min}$ and initial rates of $\left[{ }^{14} \mathrm{C}\right]$ succinate uptake were measured. The succinate concentration in the uptake assay was $625 \mu \mathrm{M}$. Since the cells divided during the experiment, all values are corrected by the factor of increased bacterial density.

Table 2. Inhibition of $\left[{ }^{14} \mathrm{C}\right]$ succinate uptake by various carbon compounds in R. meliloti 2011

Inhibitor

Unlabelled succinate

Fumarate

Malate

Glucose

$\overbrace{100 \mu \mathrm{M}-\text { Inhibitor }}^{\text {Uptake rate of }\left[{ }^{14} \mathrm{C}\right] \text { succinate }(\%)^{*}}$

48

49

65

100
11

12

18

98

* The $\left[{ }^{14} \mathrm{C}\right]$ succinate concentration was $100 \mu \mathrm{M}$. The uptake rate of $\left[{ }^{14} \mathrm{C}\right]$ succinate without inhibitor $(=100 \%)$

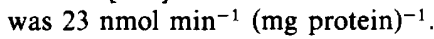

\section{RESULTS}

\section{Biochemical characterization of the $C_{4}$-dicarboxylate transport in free-living $R$. meliloti 2011}

To find out whether there is a common transport system for succinate, fumarate and malate in R. meliloti, inhibition studies were done with the wild-type strain 2011 (Table 2). Uptake rates of $\left[{ }^{14} \mathrm{C}\right]$ succinate $(100 \mu \mathrm{M})$ were measured without inhibitor or with the addition of unlabelled succinate, malate, fumarate or glucose at $100 \mu \mathrm{M}$ or $1 \mathrm{~mm}$. Uptake of succinate was strongly inhibited by unlabelled succinate, fumarate or malate, whereas glucose had no effect. To prove that the inhibition of succinate by fumarate and malate was competitive, succinate uptake rates at different succinate concentrations without inhibitor and with fumarate or malate as inhibitor were measured. When these data were fitted to the Michaelis-Menten equation (LineweaverBurk plot), the lines for the noninhibited and inhibited uptake rates met at a point close to the $y$ axis, indicating competitive inhibition (Fig. 1). This means that succinate, fumarate and malate are transported in $R$. meliloti by a common dicarboxylate transport system.

Initial $\left[{ }^{14} \mathrm{C}\right]$ succinate uptake velocities were measured at succinate concentrations between $0.5 \mu \mathrm{M}$ and $1.0 \mathrm{mM}$, and these values were fitted to the Michaelis-Menten equation. After linear regression calculations, a $K_{\mathrm{m}}$ of $5.3 \mu \mathrm{M}$ and a $V_{\max }$ of $23.9 \mathrm{nmol}(\mathrm{mg} \text { protein) })^{-1} \mathrm{~min}^{-1}$ were obtained. 
Table 3. Characteristics of $R$. meliloti mutants unable to grow on succinate as sole carbon source

\begin{tabular}{|c|c|c|c|c|c|}
\hline \multirow[b]{2}{*}{$\begin{array}{l}R . \text { meliloti } \\
\text { strain }\end{array}$} & \multirow{2}{*}{$\begin{array}{l}\text { Growth on } \\
\text { succinate, } \\
\text { malate or } \\
\text { fumarate }\end{array}$} & \multicolumn{2}{|c|}{$\begin{array}{l}\text { Dicarboxylate transport } \\
\text { in }\end{array}$} & \multirow[b]{2}{*}{$\begin{array}{l}\text { Acetylene } \\
\text { reduction }\end{array}$} & \multirow[b]{2}{*}{$\begin{array}{l}\text { Complementing } \\
\text { cosmids }\end{array}$} \\
\hline & & $\begin{array}{l}\text { Free-living } \\
\text { cells }\end{array}$ & $\begin{array}{l}\text { Symbiotic } \\
\text { cells }\end{array}$ & & \\
\hline 2011 & ++ & ++ & ++ & ++ & \\
\hline RMS11 & - & - & + & + & None \\
\hline RMS16 & - & - & NT & + & pRmSC121 \\
\hline RMS17 & - & - & + & + & $\mathrm{pRmSC} 121$ \\
\hline RMS24 & - & - & + & + & $\mathrm{pRmSC} 121$ \\
\hline RMS118 & - & - & + & + & $\mathrm{pRmSC} 121$ \\
\hline RMS420 & - & - & - & - & $\mathrm{pRmSC102/101}$ \\
\hline RMS938 & - & - & - & - & $\mathrm{pRmSC} 121$ \\
\hline
\end{tabular}

++ , Wild-type-like activity; + , reduced activity;,- no detectable activity; NT, not tested.

To determine whether the dicarboxylate transport system is constitutively expressed or is regulated as an inducible process, an $R$. meliloti 2011 culture, grown in glucose overnight, was resuspended in succinate-containing medium and the time course of the $\left[{ }^{14} \mathrm{C}\right]$ succinate uptake rate of this culture was determined (Fig. 2). Immediately after transfer to the fresh medium succinate uptake was not detectable. It took more than $50 \mathrm{~min}$ for the maximal transport rate to be reached, indicating that dicarboxylate transport is an inducible process in $R$. meliloti. As a control the same culture was grown overnight in succinate. This culture showed the maximal transport rate immediately after transfer (data not shown). When cells were grown overnight in the presence of equimolar concentrations of succinate and glucose their $\left[{ }^{14} \mathrm{C}\right]$ succinate uptake rate was comparable to that of cells pregrown in succinate only (data not shown), indicating that the dicarboxylate transport system is not repressed by glucose.

To determine whether the dicarboxylate transport system is an active or passive process, the uptake rate was measured for cells exposed to different concentrations (10 $\mu \mathrm{M}$ to $2 \mathrm{mM})$ of the uncoupler DNP prior to the addition of $\left[{ }^{14} \mathrm{C}\right]$ succinate. The inhibition of succinate uptake was more than $90 \%$ at a DNP concentration of approximately $0.5 \mathrm{~mm}$ or more, indicating that the dicarboxylate transport system in $R$. meliloti is energy dependent and therefore represents an active process.

\section{Isolation and characterization of Tn5-induced $R$. meliloti mutants defective in $C_{4}$-dicarboxylate transport}

Mutants of $R$. meliloti defective in the dicarboxylate transport system were generated by random Tn 5 mutagenesis. About $8 \times 10^{3}$ Tn5-induced mutants were tested for their colonyforming ability on succinate minimal medium. Seven colonies were found to be unable to grow on succinate minimal medium but could form colonies on glucose minimal medium.

These seven mutants (RMS11, RMS16, RMS17, RMS24, RMS118, RMS420 and RMS938) were tested for growth in liquid medium containing different carbon sources. All the mutants failed to grow with succinate, fumarate or malate (Table 3), whereas growth with pyruvate or glutamate was similar to that of the wild-type. All seven mutants also grew at approximately wild-type rates with glucose, arabinose, fructose, sucrose, maltose, galactose or lactose as carbon source.

The succinate, malate and fumarate non-utilizing mutants were examined for their ability to take up succinate under free-living conditions. Cells were grown in minimal medium plus $10 \mathrm{~mm}$-succinate and $10 \mathrm{~mm}$-glucose to allow the initial growth of cells and induction of the dicarboxylate transport system. The cells were extensively washed, resuspended in minimal medium plus succinate and uptake rates were measured (Fig. 3). While the wild-type strain took up succinate, the seven mutants showed no detectable uptake. Similar results were obtained for malate (data not shown). These results indicate the absence of a functional dicarboxylate transport system in all seven mutants under free-living conditions. These mutants were therefore 


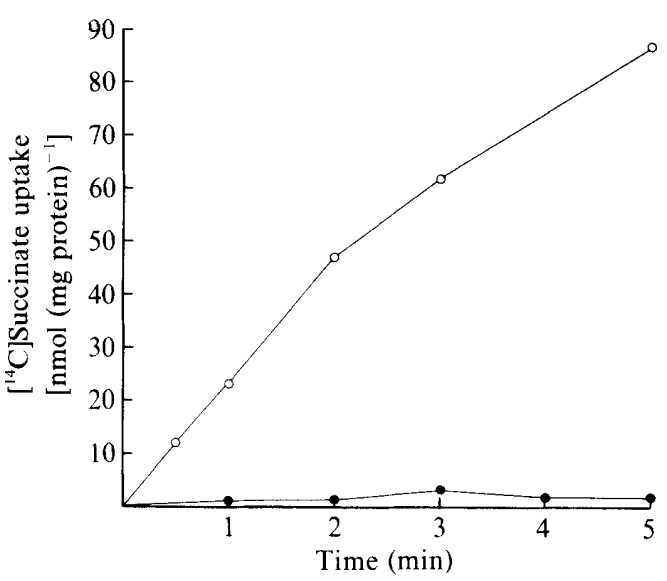

Fig. 3

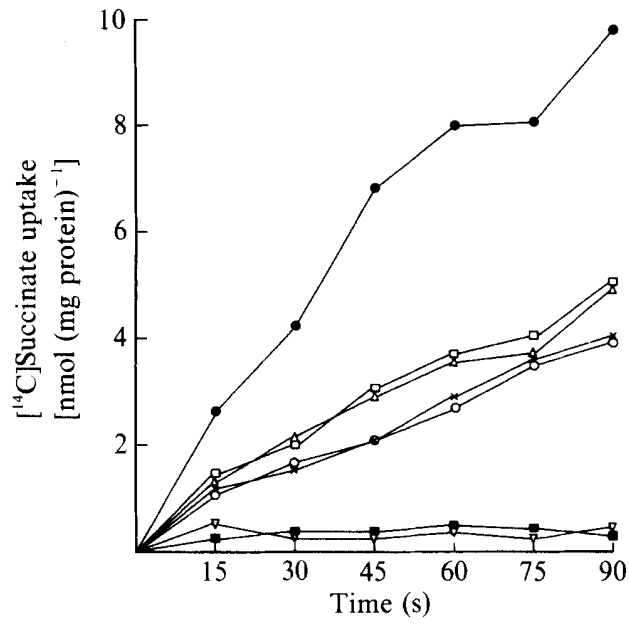

Fig. 4

Fig. 3. Succinate uptake of the $R$. meliloti wild-type strain $2011(O)$ and the mutant strain RMS11 (O) in the free-living state. Cells were grown in minimal medium plus glucose $(10 \mathrm{~mm})$ and succinate $(10 \mathrm{mM})$, then washed and resuspended in minimal medium plus succinate. The succinate uptake of mutants RMS16, RMS17, RMS24, RMS118, RMS420 and RMS938 was similar to that of RMS11 (data not shown).

Fig. 4. Succinate uptake by bacteroids isolated from nodules induced by $R$. meliloti wild-type and mutant strains. Uptake rates were determined immediately after bacteroid isolation. Wild-type strain $2011 ; \square$, RMS11; O, RMS17; $\Delta$, RMS24; $\times$, RMS118; $\nabla$, RMS420; , RMS938.

designated Dctfl- ${ }^{-}$. Revertants of all mutants (RMS938 was not tested) which were isolated on minimal medium plus succinate could also grow on malate and fumarate again.

The R. meliloti wild-type strain 2011 and the seven mutants were also tested for their ability to take up $\left[{ }^{14} \mathrm{C}\right]$ succinate and $\left[{ }^{14} \mathrm{C}\right]$ malate in the bacteroid state. Alfalfa seedlings were inoculated with the wild-type and also with the mutant strains. After $21 \mathrm{~d}$ growth, plants were harvested and bacteroids were isolated from the nodules. Uptake rates for succinate (Fig. 4) and malate (data not shown) were determined. Bacteroids of mutants RMS11, RMS17, RMS24 and RMS118 took up succinate and malate, although at only $30-50 \%$ of the wild-type rate. Bacteroids of mutants RMS420 and RMS938 did not show uptake activity with either succinate or malate (Table 3). These results suggest that the mutants RMS11, RMS17, RMS24 and RMS1 18 can be characterized in the symbiotic state by a reduced activity of the dicarboxylate transport system (Dcts ${ }^{\text {red}}$ ), whereas the mutants RMS420 and RMS938 are defective in the dicarboxylate transport system (Dcts ${ }^{-}$).

Further experiments revealed that the succinate and malate uptake activity of the mutants was correlated with their nitrogen-fixation activity (Table 3 ). When the ability of bacteroids in nodules to reduce acetylene to ethylene was measured at the harvest time $(21 \mathrm{~d})$, mutants RMS420 and RMS938 did not show any acetylene reduction. The nodules induced by these mutants were small and white. These two mutants are evidently $\mathrm{Fix}^{-}$. All other mutants showed acetylene reduction, although at a lower rate than the wild-type (Table 3). These mutants gave rise to pink nodules of normal size. This class of mutants is therefore considered to be Fix ${ }^{\text {red. }}$.

\section{Characterization of cosmid clones that complement different $C_{4}$-dicarboxylate transport mutants}

In order to isolate DNA fragments carrying $d c t$ genes, the mutants described so far were each used as recipients for cosmids of an $R$. meliloti 2011 clone bank which were introduced en masse into the mutants. $\mathrm{Tc}^{\mathrm{r}}$ transconjugants were obtained from all mating mixtures at a frequency of $10^{-4}$ per recipient after $4-5 \mathrm{~d}$ growth. Two cosmids, designated $\mathrm{pRmSC101}$ and $\mathrm{pRmSC102}$, restored growth of the Fix ${ }^{-}$mutant RMS420 on succinate, fumarate and malate (Table 3 ). Plant 


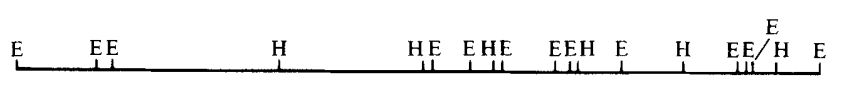

\begin{tabular}{|c|c|c|c|c|c|}
\hline$E$ & $\mathrm{H}$ & $\mathrm{H}$ & $\mathrm{H}$ & $\mathrm{H}$ & $\stackrel{\mathrm{H}}{\mathrm{H}}$ \\
\hline E & $\stackrel{\mathbf{H}}{\mathbf{L}}$ & $\mathrm{H}$ & $\mathrm{H}$ & $\mathrm{H}$ & $\mathrm{H}$ \\
\hline E & $\underset{\mathrm{H}}{\mathrm{H}}$ & $\stackrel{H}{H}$ & $\mathbf{H}$ & & $\mathrm{H}$ \\
\hline E & $\stackrel{H}{\mathcal{H}}$ & ${ }^{H}$ & & & $\stackrel{\mathrm{H}}{ }$ \\
\hline & $H^{H}$ & & & & H \\
\hline
\end{tabular}

pRmSC102

$\mathrm{pRmSC102H1}$

$\mathrm{pRmSC102H} 2$

$\mathrm{pRmSC102 \textrm {H } 3}$

$\mathrm{pRmSCl} 102 \mathrm{H} 4$

$\mathrm{pRmSC102 \textrm {H } 5}$ $\overbrace{(a) \text { Growth }(b)}^{\mathbf{N}_{2^{-}}}$fixation

$+\quad+$

$\begin{array}{lllll}E & 12.5 \mathrm{~kb} & \text { H } & 6.9 \mathrm{~kb} & \mathrm{H}\end{array}$

$1 \mathrm{~kb}$

Fig. 5. Complementation analysis of $R$. meliloti mutant RMS420 by partially deleted inserts of pRmSC102. A restriction map of the EcoRI insert of cosmid pRmSC102 is shown. By partial HindIII digestion, five different deletion cosmids (pRmSC102H1, - $\mathrm{H} 2,-\mathrm{H} 3,-\mathrm{H} 4,-\mathrm{H} 5)$ were constructed. The locations of the individual deletions are indicated. The ability of these deletion cosmids to complement mutant RMS420 was tested $(a)$ by growth on succinate, malate or fumarate and $(b)$ by an assay to form effective nodules. The EcoRI-HindIII fragment indicated at the bottom is evidently necessary for complementation of mutant RMS420 whereas the indicated $15.3 \mathrm{~kb} E c o$ RI fragment carries the $\operatorname{Tn} 5$ transposon in mutant RMS420 (see Fig. 6).

tests of RMS420(pRmSC101) and RMS420(pRmSC102) indicated that the effective symbiotic nitrogen-fixation phenotype was also restored to the wild-type level. Both pRmSC101 and pRmSC102 were unable to complement any of the other mutants described in Table 3.

A third cosmid clone, pRmSC121, was isolated from the gene bank, which complemented most of the other dicarboxylate transport mutants. Cosmid pRmSC121 restored growth on succinate, malate and fumarate for mutants RMS16, RMS17 and RMS24, RMS118 and RMS938 (Table 3). The frequency of complementation for the different mutants differed widely and has to be investigated by a detailed analysis in future. Interestingly, cosmid pRmSC121 did not complement mutant RMS420 complemented by cosmids pRmSC101 and pRmSC102, which means that the two groups of isolated cosmids do not cross-complement the mutants under investigation.

To analyse the recombinant cosmids, $\mathrm{pRmSC} 101$ and $\mathrm{pRmSC} 102$ cosmid DNA was isolated on a large scale from $E$. coli $\mathrm{K} 802$ and analysed by $E c o \mathrm{RI}$ and $H i n \mathrm{dIII}$ restriction endonucleases. The vector pSUP205 contains single EcoRI and HindIII cleavage sites, and restriction with $E c o$ RI separates the vector from the insert fragments in the cosmids. The restriction pattern of the two cosmids revealed the presence of ten $E c o$ RI and six HindIII fragments in pRmSC101 with a total size of approximately $43 \mathrm{~kb}$, and thirteen EcoRI and seven HindIII fragments in $\mathrm{pRmSC102}$ with a total size of $47 \mathrm{~kb}$. Cosmid pRmSC102 contained all the EcoRI fragments of pRmSC101 and three extra EcoRI fragments extending pRmSC101 at the right-hand end. The larger cosmid $\mathrm{pRmSC} 102$ was used for further analysis.

HindIII cleaved pRmSC102 into seven fragments. The order of the HindIII fragments within pRmSC102 was established (Fig. 5) by partial digestion and ligation followed by transformation of $E$. coli $\mathrm{S} 17.1$ and analysis of plasmid DNA from the transformants. The ordering was based on the frequency of the individual HindIII fragments present or absent in the religated plasmid DNA molecules. A number of hybrid plasmids containing deletions of various HindIII fragments were generated in this experiment; these plasmids are shown in Fig. 5. The HindIII fragments flanking the vector DNA were verified by hybridization of the HindIII-restricted pRmSC102 DNA with ${ }^{32}$ P-labelled vector pSUP205 DNA. The relative positions of the 


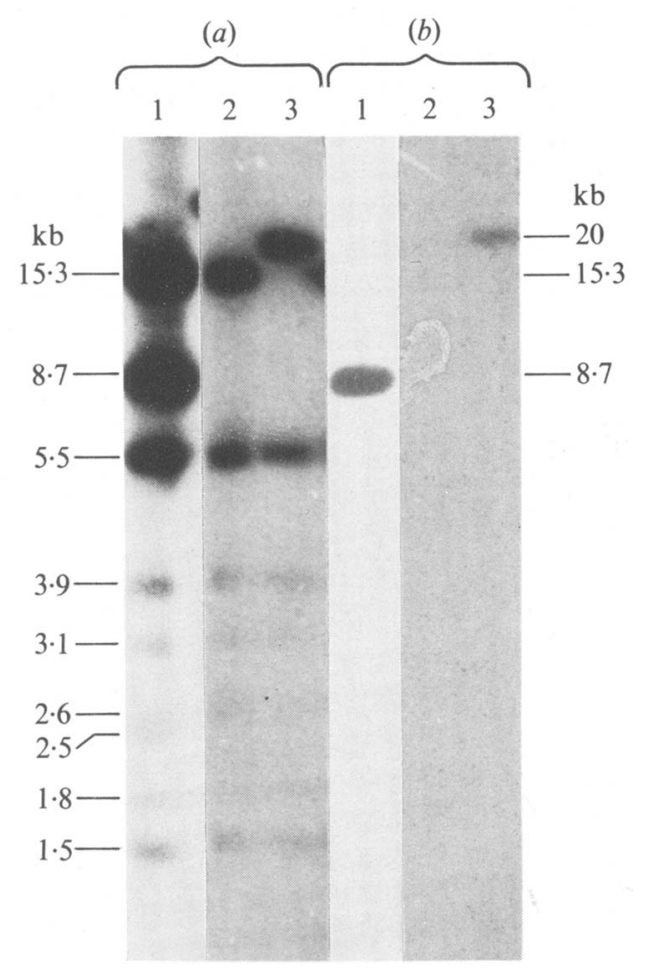

Fig. 6. Southern hybridization analysis to localize the site of Tn 5 insertion in mutant RMS420. DNA of cosmid pRmSC102 (lanes 1), and total DNA of wild-type 2011 (lanes 2) and mutant RMS420 (lanes 3) was restricted with $E c o$ RI, separated by agarose gel electrophoresis, transferred to nitrocellulose filters and probed with ${ }^{32} \mathrm{P}$-labelled pRmSC102 (a) or pSUP5011 (containing Tn5) (b). The $8.7 \mathrm{~kb}$ fragment represents vector DNA.

restriction sites for $E c o$ RI and $B a m H I$ were identified by single and double digestions of purified pRmSC102 DNA, and the various restriction endonuclease cleavage sites are shown in Fig. 5.

Further proof for the location of the mutation in mutant RMS420, presumably due to Tn5 insertion, was obtained by complementation analysis involving various deletion derivatives of pRmSC102 (Fig. 5). Hybrid cosmids containing deletions were mobilized from E. coli S17.1 by conjugation into mutant RMS420. $\mathrm{Sm}^{\mathrm{r}} \mathrm{Tc}^{\mathrm{r}}$ transconjugants were isolated and tested for growth

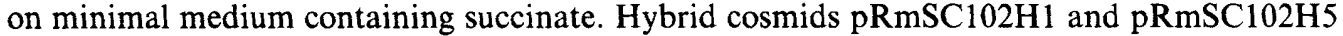
were unable to complement for growth on succinate. The remaining three $\mathrm{pRmSC102H}$ cosmids were able to complement mutant RMS420, indicating that the complementing region was located in the $6.9 \mathrm{~kb}$ HindIII fragment and perhaps partly in the adjacent large EcoRI-HindIII fragment (Fig. 5). The hybrid cosmids containing these two fragments were also able to restore the nitrogen-fixation phenotype to the wild-type level. The restriction analysis of $\mathrm{pRmSC102}$ indicated that the $6.9 \mathrm{~kb}$ HindIII fragment was present within the large $15 \mathrm{~kb}$ EcoRI fragment.

\section{Mapping of the Tn5 insertion site of mutant RMS420}

To localize the site of insertion of transposon Tn 5 in mutant RMS420, Southern hybridization experiments were done. Total DNA was isolated from the wild-type strain 2011 and mutant RMS420, restricted with EcoRI, separated by agarose gel electrophoresis $(0.7 \%)$ and transferred to nitrocellulose filters. The nitrocellulose blots were hybridized to ${ }^{32} \mathrm{P}$-labelled $\mathrm{pRmSC} 102$ DNA. Tn 5 contains no EcoRI recognition sites. If the site of the Tn 5 insertion is in the region of the genome corresponding to the complementing cosmid $\mathrm{pRmSC102}$, then the altered fragment should hybridize to the ${ }^{32}$ P-labelled plasmid. Thus, while in the wild-type the pattern of 
hybridization bands should be like that of pRmSC102 itself, in the mutant RMS420 the EcoRI fragment containing $\mathrm{Tn} 5$ should alter by the addition of the size of $\mathrm{Tn} 5(5.75 \mathrm{~kb}$, Reznikoff, 1982). The autoradiogram shown in Fig. 6 revealed the alteration of the largest EcoRI fragment (corresponding to a size of approximately $20 \mathrm{~kb}$ ) in the mutant but not in the wild-type, indicating the presence of $\mathrm{Tn} 5$ in this fragment. The largest fragment in $\mathrm{pRmSCl} 02$ had a size of approximately $15 \mathrm{~kb}$. A duplicate nitrocellulose blot was hybridized to ${ }^{32} \mathrm{P}$-labelled pSUP5011 DNA (containing $\operatorname{Tn} 5$ ). While there was no hybridization to the wild-type DNA, a fragment of approximately $20 \mathrm{~kb}$ in the mutant DNA did hybridize (Fig. 6), consistent with the previous indication that $\mathrm{Tn} 5$ was located in the $15 \mathrm{~kb} E c o \mathrm{RI}$ fragment. When the two autoradiograms were superimposed, the two bands were present in the same position.

\section{DISCUSSION}

The $\mathrm{C}_{4}$-dicarboxylate transport system of free-living $R$. meliloti 2011 was investigated by physiological and genetic studies. It was shown that succinate uptake is strongly inhibited by fumarate and malate and that this inhibition is competitive. These results were confirmed by a mutational analysis. Tn5-induced mutants which could not grow on succinate, also did not grow on fumarate or malate but did grow on other carboxylic acids (pyruvate and glutamate). Revertants of the mutants grew on all three dicarboxylic acids again. Succinate uptake and malate uptake in these mutants were absent. All these results give evidence for a functional $\mathrm{C}_{4}$ dicarboxylic acid transport system in free-living $R$. meliloti. Dicarboxylate transport systems in free-living cells have been shown in E. coli (Kay \& Kornberg, 1971; Lo et al., 1972), Bacillus subtilis (Ghei \& Kay, 1973), Azotobacter vinelandii (Reuser \& Postma, 1973), Pseudomonas putida (Dubler et al., 1974), Salmonella typhimurium (Kay \& Cameron, 1978), 'R. trifolii' (Ronson et al., 1981), R. leguminosarum (Glenn et al., 1980; Finan et al., 1981) and Bradyrhizobium japonicum (McAllister \& Lepo, 1983; San Francisco \& Jacobson, 1985). Succinate-uptake-deficient mutants of $R$. meliloti were recently described by Bolton et al. (1986).

The dicarboxylate transport system in free-living $R$. meliloti is inducible by succinate within more than $50 \mathrm{~min}$. The system is not induced if glucose is the only carbon source, which was also reported for fast-growing cowpea rhizobia (Saroso et al., 1984). In contrast, an equimolar mixture of succinate and glucose keeps the system induced, indicating that glucose does not suppress the dicarboxylate transport system in $R$. meliloti. Partial supression by glucose was reported for ' $R$. trifolii' by Ronson et al. (1981). Inducible dicarboxylate transport systems have been found in ' $R$. trifolii' (Ronson et al., 1981), R. leguminosarum (Finan et al., 1981) and $B$. japonicum (McAllister \& Lepo, 1983), while constitutive dicarboxylate transport systems were reported for $R$. leguminosarum (Glenn et al., 1980) and two Bradyrhizobium species (San Francisco \& Jacobson, 1985). The dicarboxylate transport system in free-living $R$. meliloti is energy dependent, as judged by the effects of DNP. More information is required about the precise link of the dicarboxylate transport system to an energy source in Rhizobium.

Seven mutants lacking the dicarboxylate transport system under free-living conditions $\left(\mathrm{Dctfl}^{-}\right)$were isolated. After differentiation of free-living cells into bacteroids in alfalfa nodules, only the two mutants RMS420 and RMS938 were still dicarboxylate transport deficient (Dcts ${ }^{-}$), whereas bacteroids of four other mutants (RMS11, RMS17, RMS24 and RMS118) showed active dicarboxylate transport but at a reduced rate (Dcts ${ }^{\text {red }}$ ). We do not know the nature of the differences between these two systems. However, it may be that there exists a complex regulation responsible for the expression of the relevant genes under free-living and symbiotic conditions. Dcts ${ }^{-}$mutants RMS420 and RMS938 were Fix $^{-}$, whereas Dets ${ }^{\text {red }}$ mutants RMS11, RMS17, RMS24 and RMS1 18 were also Fix ${ }^{\text {red }}$. This correlation suggests that the $\mathrm{C}_{4^{-}}$ dicarboxylate transport in bacteroids is limiting the nitrogen-fixation capacity of nodules. In addition, one can speculate that it may be possible to enhance symbiotic nitrogen fixation by improving dicarboxylate transport in bacteroids (see Bolton et al., 1986).

Other authors have stated that a functional dicarboxylate transport system is not necessary for nodulation (Ronson et al., 1981; Finan et al., 1983; Arwas et al., 1985). The same result was obtained in this investigation. Nodules induced by Dcts ${ }^{-}$mutants were smaller than wild-type 
nodules and their white colour indicated the absence of leghaemoglobin. The nodules were colonized by bacteroids and the typical zonation could be detected by light microscopy (D. Kapp, personal communication).

Genetic complementation of the $\mathrm{Fix}^{-}$mutant RMS420 with the cosmids pRmSC101 or $\mathrm{pRmSC} 102$ always resulted in growth on succinate and in the restoration of nitrogen-fixation capacity to the wild-type level. We know from our genetic studies that the complementing information is located on a $19.4 \mathrm{~kb}$ Eco RI-HindIII fragment containing a $6.9 \mathrm{~kb}$ HindIII fragment. Hybridization data suggest that the Tn 5 transposon of mutant RMS420 is located on a $15.3 \mathrm{~kb}$ EcoRI fragment which includes the $6.9 \mathrm{~kb}$ HindIII fragment. Both pRmSC101 and $\mathrm{pRmSC} 102$ were unable to complement the other mutants. A third cosmid, pRmSC121, showed a completely different complementation pattern, complementing the Fix ${ }^{-}$mutant RMS938 and most of the Fix ${ }^{\text {red }}$ mutants. Thus it seems that this cosmid carries most of the genetic information coding for $\mathrm{C}_{4}$-dicarboxylate transport in $R$. meliloti.

Our results indicate the importance of the $\mathrm{C}_{4}$-dicarboxylate transport system for symbiotic nitrogen fixation in $R$. meliloti. Isolation of two unrelated cosmids complementing most of the mutants provides material for a detailed molecular analysis in the future.

We thank Dr P. Gresshoff and M. Keller for critical reading of the manuscript. This work was financed by the Agrigenetics Research Corporation, Boulder, Colorado, USA.

\section{REFERENCES}

ARWas, R., MCKay, I. A., Rowney, F. R. P., Dilworth, M. J. \& GlenN, A. R. (1985). Properties of organic acid utilization mutants of Rhizobium leguminosarum strain 300. Journal of General Microbiology 131, 2059-2066.

Bolton, E., Higgisson, B., Harrington, A. \& O'GARA, F. (1986). Dicarboxylic acid transport in Rhizobium meliloti: isolation of mutants and cloning of dicarboxylic acid transport genes. Archives of Microbiology 144, 142-146.

Clewell, D. D. \& Helinski, D. R. (1969). Supercoiled circular DNA protein complex in Escherichia coli: purification and induced conversion to an open circular form. Proceedings of the National Academy of Sciences of the United States of America 62, 11591166.

DE VRies, G. E., van Brussel, A. A. N. \& Quispel, A. (1982). Mechanism and regulation of glucose transport in Rhizobium leguminosarum. Journal of Bacteriology 149, 872-879.

Dubler, R. E., Toscano, W. A. \& Hartline, R. A. (1974). Transport of succinate by Pseudomonas putida. Archives of Biochemistry and Biophysics 160, $422-429$.

Duncan, M. J. (1981). Properties of Tn5-induced carbohydrate mutants in Rhizobium meliloti. Journal of General Microbiology 122, 61-67.

Duncan, M. J. \& FraenKel, D. G. (1979). $\alpha$ Ketoglutarate dehydrogenase mutant of Rhizobium meliloti. Journal of Bacteriology 137, 415-419.

Finan, T. M., WoOd, J. M. \& Jordan, D. C. (1981). Succinate transport in Rhizobium leguminosarum. Journal of Bacteriology 148, 193-202.

FinaN, T. M., WoOd, J. M. \& JoRdan, D. C. (1983). Symbiotic properties of $\mathrm{C}_{4}$-dicarboxylic acid transport mutants of Rhizobium leguminosarum. Journal of Bacteriology 154, 1403-1413.

Gardiol, A., Arias, A., Cervenansky, C. \& MarTINEZ-DRETZ, G. (1982). Succinate dehydrogenase mutant of Rhizobium meliloti. Journal of Bacteriology 151, 1621-1623.

GheI, O. K. \& KAY, W. W. (1973). Properties of an inducible $\mathrm{C}_{4}$-dicarboxylate transport system in Bacillus subtilis. Journal of Bacteriology 114, 65-79.

GlenN, A. R. \& DilworTH, M. J. (1981). The uptake and hydrolysis of disaccharides by fast and slow growing species of Rhizobium. Archives of Microbiology 128, 72-77.

GlenN, A. R., Poole, P. S. \& Hudman, J. F. (1980). Succinate uptake by free living and bacteroid forms of Rhizobium leguminosarum. Journal of General Microbiology 119, 267-271.

GlenN, A. R., MCKay, I. A., ARWas, R. \& DILWORTH, M. J. (1984). Sugar metabolism and symbiotic properties of carbohydrate mutants of Rhizobium leguminosarum. Journal of General Microbiology 130, 239-245.

Hudman, J. F. \& GlenN, A. R. (1980). Glucose uptake by free-living and bacteroid forms of Rhizobium leguminosarum. Archives of Microbiology 128, 72-77.

Hynes, M. F., Simon, R., Müller, P., Niehaus, K., LABES, M. \& PüHleR, A. (1986). The two megaplasmids of Rhizobium meliloti are involved in the effective nodulation of alfalfa. Molecular and General Genetics 202, 356-362.

ISH-Horowicz, D. \& BURKE, J. F. (1981). Rapid and efficient cosmid cloning. Nucleic Acids Research 9, 2989-2998.

JaGaDish, M. N. \& Szalay, A. A. (1984). Directed transposon $\operatorname{Tn} 5$ mutagenesis and complementation in slow-growing broad host range cowpea Rhizobium. Molecular and General Genetics 196, 290-300.

KAY, W. W. \& Cameron, M. J. (1978). Transport of $\mathrm{C}_{4}$-dicarboxylic acids in Salmonella typhimurium. Archives of Biochemistry and Biophysics 190, 281-289.

KAY, W. W. \& KORNBERG, H. L. (1971). Transport of $\mathrm{C}_{4}$-dicarboxylic acids by Escherichia coli. European Journal of Biochemistry 18, 274-281. 
Lo, T. C. Y., Rayman, M. K. \& Sanwal, B. D. (1972). Transport of succinate in Escherichia coli. Journal of Biological Chemistry 247, 6323-6331.

Maniatis, T., Fritsch, E. F. \& Sambrook, J. (1982). Molecular Cloning - a Laboratory Manual. Cold Spring Harbor, NY: Cold Spring Harbor Laboratory.

MCAllister, C. F. \& LePo, J. E. (1983). Succinate transport by free-living form of Rhizobium japonicum. Journal of Bacteriology 153, 1155-1162.

MCKay, I. A., GlenN, A. R. \& Dilworth, M. J. (1985). Gluconeogenesis in Rhizobium leguminosarum MNF 3841. Journal of General Microbiology 131, 2067-2073.

Reuser, A. J. J. \& Postma, P. W. (1973). The induction of translocators for di- and tricarboxylic acid anions in Azotobacter vinelandii. European Journal of Biochemistry 33, 584-592.

REZNIKOFF, W. S. (1982). Tn5 transposition and its regulation. Cell 31, 307-308.

Ronson, C. M. \& Primrose, S. B. (1979). Carbohydrate metabolism in Rhizobium trifolii: identification and symbiotic properties of mutants. Journal of General Microbiology 112, 77-88.

Ronson, C. W., Lyttleton, P. \& Robertson, J. G. (1981). C 4 -dicarboxylate transport mutants of Rhizo- bium trifolii from ineffective nodules on Trifolium repens. Proceedings of the National Academy of Sciences of the United States of America 78, 42844288.

San Francisco, M. J. D. \& JaCobson, G. R. (1985). Uptake of succinate and malate in cultured cells and bacteroids of two slow growing species of Rhizobium. Journal of General Microbiology 131, 765-773.

Saroso, S., Glenn, A. R. \& Dilworth, M. J. (1984). Carbon utilization by free-living and bacteroid forms of cowpea Rhizobium strain NGR234. Journal of General Microbiology 130, 1809-1814.

Saroso, S., Dilworth, M. J. \& GlenN, A. R. (1986). The use of activities of carbon catabolic enzymes as a probe for the carbon nutrition of snakebean nodule bacteroids. Journal of General Microbiology 132, 243249.

SimON, R. (1984). High frequency mobilisation of gram-negative bacterial replicons by the in vitro constructed Tn5-Mob transposon. Molecular and General Genetics 196, 413-420.

Simon, R., Priefer, U. \& PÜHLer, A. (1983). A broad host range mobilization system for in vivo genetic engineering: transposon mutagenesis in gram-negative bacteria. Biotechnology 1, 784-791. 